OPEN ACCESS

Edited by:

Fuyu Yang,

China Agricultural University, China

Reviewed by:

Roberta Comunian,

Sardegna Agricoltura, Italy

Yanhong Yan,

Sichuan Agricultural University, China

${ }^{*}$ Correspondence:

Yurui Sun

ysun@uni-bonn.de

${ }^{\dagger}$ These authors have contributed equally to this work

Specialty section:

This article was submitted to

Microbiotechnology,

a section of the journal

Frontiers in Microbiology

Received: 28 February 2021

Accepted: 29 June 2021

Published: 12 August 2021

Citation:

Shan G, Rosner V, Milimonka A,

Buescher W, Lipski A, Maack C, Berchtold W, Wang Y, Grantz DA and

Sun $Y$ (2021) A Multi-Sensor

Mini-Bioreactor to Preselect Silage Inoculants by Tracking Metabolic

Activity in situ During Fermentation.

Front. Microbiol. 12:673795.

doi: 10.3389/fmicb.2021.673795

\section{A Multi-Sensor Mini-Bioreactor to Preselect Silage Inoculants by Tracking Metabolic Activity in situ During Fermentation}

Guilin Shan ${ }^{1+}$, Victoria Rosner ${ }^{21}$, Andreas Milimonka ${ }^{2 \dagger}$, Wolfgang Buescher ${ }^{1}$, André Lipski ${ }^{3}$, Christian Maack ${ }^{1}$, Wilfried Berchtold ${ }^{1}$, Ye Wang ${ }^{1}$, David A. Grantz ${ }^{4}$ and Yurui Sun ${ }^{* t}$

${ }^{1}$ Department of Agricultural Engineering, University of Bonn, Bonn, Germany, ${ }^{2} A D D C O N$ GmbH, Bitterfeld-Wolfen, Germany, ${ }^{3}$ Institute of Nutrition and Food Science, University of Bonn, Bonn, Germany, ${ }^{4}$ Department of Botany and Plant Sciences, Kearney Agricultural Center, University of California, Riverside, Riverside, CA, United States

The microbiome in silage may vary substantially from the onset to the completion of fermentation. Improved additives and inoculants are being developed to accelerate the ensiling process, to enhance fermentation quality, and to delay spoilage during feedout. However, current methods for preselecting and characterizing these amendments are time-consuming and costly. Here, we have developed a multi-sensor mini-bioreactor (MSMB) to track microbial fermentation in situ and additionally presented a mathematical model for the optimal assessment among candidate inoculants based on the Bolza equation, a fundamental formula in optimal control theory. Three sensors $\left[\mathrm{pH}, \mathrm{CO}_{2}\right.$, and ethanol $(\mathrm{EtOH})$ ] provided data for assessment, with four additional sensors $\left(\mathrm{O}_{2}\right.$, gas pressure, temperature, and atmospheric pressure) to monitor/control the fermentation environment. This advanced MSMB is demonstrated with an experimental method for evaluating three typical species of lactic acid bacteria (LAB), Lentilactobacillus buchneri (LB) alone, and LB mixed with Lactiplantibacillus plantarum (LBLP) or with Enterococcus faecium (LBEF), all cultured in De Man, Rogosa, and Sharpe (MRS) broth. The fermentation process was monitored in situ over $48 \mathrm{~h}$ with these candidate microbial strains using the MSMB. The experimental results combine acidification characteristics with production of $\mathrm{CO}_{2}$ and $\mathrm{EtOH}$, optimal assessment of the microbes, analysis of the metabolic sensitivity to $\mathrm{pH}$, and partitioning of the contribution of each species to fermentation. These new data demonstrate that the MSMB associated with the novel rapid data-processing method may expedite development of microbial amendments for silage additives.

Keywords: lactic acid bacteria (LAB), multi-sensor mini-bioreactor (MSMB), fermentation, silage additive, metabolic sensitivity, $\mathrm{pH}$, carbon dioxide $\left(\mathrm{CO}_{2}\right)$, ethanol $(\mathrm{EtOH})$

\section{INTRODUCTION}

Silage is a major feedstuff for ruminant animal production worldwide. The biochemical production of silage relies on anaerobic lactic acid fermentation. Homofermentative lactic acid bacteria (LAB) ferment glucose to lactic acid as the primary by-product, whereas heterofermentative LAB ferment glucose to lactic acid, acetic acid, ethanol (EtOH), and carbon dioxide $\left(\mathrm{CO}_{2}\right)$ 
(Muck, 2004; Kung et al., 2018a; Muck et al., 2018). Testing for heterofermentative fermentation generally involves gas phase sampling of $\mathrm{CO}_{2}$ and EtOH (McEniry et al., 2011; Li et al., 2017; Kung et al., 2018b).

Though silage is a nutritious and palatable animal feed, its aerobic deterioration is inevitable when the silo is opened for feeding out, but spoilage can be reduced significantly using either biological or chemical additives (Ranjit and Kung, 2000; Borreani and Tabacco, 2010; Tabacco et al., 2011; Wilkinson and Davies, 2012). Commercial silage inoculants contain highly selected bacteria that speed up silage acidification during anaerobic fermentation (Queiroz et al., 2013; Muck et al., 2018). This typically involves strains of facultative heterofermentative bacteria such as Lactiplantibacillus plantarum (LP), and obligate heterofermentative bacteria such as Lentilactobacillus buchneri (LB) are used to enhance the aerobic stability of silage (Bolsen et al., 1996; Kung et al., 2018a; Muck et al., 2018). Rapid acidification significantly inhibits the growth of undesirable microorganisms and reduces fermentative loss, while acetic acid, the by-product of heterofermentation, suppresses the aerobic proliferation of spoilage-causing fungi and minimizes oxidative losses during feed-out (Pahlow et al., 2003; Muck, 2004; Kung et al., 2018b).

To continuously improve these biological silage additives requires selection of improved microbial strains from among the abundant species and strains of LAB that are present in natural populations (Muck et al., 2018). Selection is commonly performed during the natural ensiling process, which is timeconsuming, laborious, and costly, requiring large numbers of ex situ samples and intensive laboratory analyses (Weinberg and Ashbell, 2003). To resolve these bottlenecks in research for silage inoculants, this study presents a multi-sensor-based screening method with three major objectives: (i) to present an alternative model for selecting microbes, (ii) to devise a multisensor mini-bioreactor (MSMB) for screening microbial strains during fermentation in situ, and (iii) to evaluate the capabilities of the advanced MSMB in selection among candidate inoculants.

\section{MATERIALS AND METHODS}

\section{Microbial Selection and Optimal Fermentation}

With the use of control system theory (Sargent, 2000), a LAB fermentation process $[X(t)]$ can be described as a set of state variables $\left[x_{1}(t)-x_{3}(t)\right]$ under microbial control $u_{m}$ such that

$$
\begin{gathered}
\dot{X}=\left[\begin{array}{c}
\dot{x}_{1} \\
\dot{x}_{2} \\
\dot{x}_{3}
\end{array}\right]=F\left[\left(x_{1}(t), x_{2}(t), x_{3}(t), u_{\mathrm{m}}, t\right)\right] \\
\text { with } \mathrm{t}_{0} \leq \mathrm{t} \leq \mathrm{t}_{\mathrm{f}}
\end{gathered}
$$

where $x_{1}, x_{2}$, and $x_{3}$ refer to the accumulated productions of organic acids (lactic and acetic), $\mathrm{CO}_{2}$, and $\mathrm{EtOH}$, respectively, with respect to the initial time $\left(t_{0}\right)$ and the final time $\left(t_{f}\right)$ of fermentation. As the function of time $(t)$, these state variables can be expressed as the outputs of triple integrators such that

$$
\left.\begin{array}{c}
x_{1}(t)=\frac{1}{\mathrm{pH}(t)}=\int_{t_{0}}^{t}[\mathrm{acid}] \mathrm{dt} \\
x_{2}(t)=\int_{t_{0}}^{t}\left[\mathrm{CO}_{2}\right] \mathrm{dt} \\
x_{3}(t)=\int_{t_{0}}^{t}[\mathrm{EtOH}] \mathrm{dt}
\end{array}\right\}
$$

where [acid] is the instantaneous production of organic acids (primary lactic and acetic), resulting from LAB fermentation. Similar representations apply to carbon dioxide $\left[\mathrm{CO}_{2}\right]$ and [EtOH]. According to optimal control theory (Sargent, 2000), an optimal/minimum cost function of $\hat{J}$ subject to Eq. 2 exists, and an optimal control $\left(\hat{\mathrm{U}}_{m-\text { best }}\right)$ fulfills

$$
\begin{aligned}
& \hat{\mathrm{J}}\left(\hat{\mathrm{u}}_{\mathrm{m}-\text { best }}\right)=\min \cdot\left(x_{1}+x_{2}+x_{3}\right) \\
= & \min \cdot\left(t_{f}-t_{0}\right)_{\mathrm{pH} \downarrow}+\min \cdot \int_{t_{0}}^{\min \cdot t_{f}}\left[\mathrm{CO}_{2}(t)\right] \mathrm{dt} \\
+ & \min \cdot \int_{t_{0}}^{\min \cdot t_{f}}[\mathrm{EtOH}(t)] \mathrm{dt}
\end{aligned}
$$

where $\min .\left(t_{f}-t_{0}\right)_{p H \downarrow}$ is the shortest time of acidification dynamics of Eq. 1, i.e., the optimal time to be determined by fermentation. The two integrations of $x_{2}(t)$ and $x_{3}(t)$ are related to minimum fermentative loss. Eq. 3 is a special case of the generalized problem of Bolza (Clarke, 1976; Sargent, 2000), which contains a global solution of the time-energy optimization subject to an optimal control function $\left(\hat{\mathrm{u}}_{m-\text { best }}\right)$. In this study, the optimal time-energy trajectories of fermentation were determined experimentally by selecting candidate microbes.

\section{Multi-Sensor-Based Experimental System}

The instrumental structure of the MSMB (Figure 1) contains seven different functional sensors (Table 1), with six enclosed in an air-tight chamber. According to Eq. 2, pH, $\mathrm{CO}_{2}$, and EtOH are the three indicators of the LAB fermentation, each corresponding to an analog integrator. Additionally, micro-environmental parameters, i.e., $\mathrm{O}_{2}$ concentration, ambient temperature $\left(T_{a}\right)$, and gas pressure $\left(P_{\text {gas }}\right)$ in the sealed chamber, were measured during the fermentation process. $P_{\text {gas }}$ was measured relative to ambient air pressure $\left(P_{\text {air }}\right)$, which was measured using a digital barometer placed on the outside of the sealed chamber (Figure 1). Throughout the test, $P_{\text {gas }}$ remains positive $\left(P_{\text {gas }}>P_{\text {air }}\right)$ due to accumulation of $\mathrm{CO}_{2}$ and volatile EtOH. The $P_{\text {gas }}$ measurement has two functions: (i) to determine the seal characteristics of the chamber before and during the experiment and (ii) to compensate the $\mathrm{O}_{2}$ measurement since the optical $\mathrm{O}_{2}$ sensor was calibrated under $P_{\text {air }}$.

The MSMB including the air-tight chamber (glass jar, $1.5 \mathrm{~L}$ ) is schematically shown in Figure 2. A centrifuge tube (inner diameter $2.5 \mathrm{~cm}$, height $12 \mathrm{~cm}$ ) was filled with fermentation medium (orange color) for culturing the candidate LAB. The $\mathrm{pH}$ electrode was immersed in the medium, as the integrator to determine the acidification characteristics of the fermentation relative to each strain or species. The resulting gas from the 


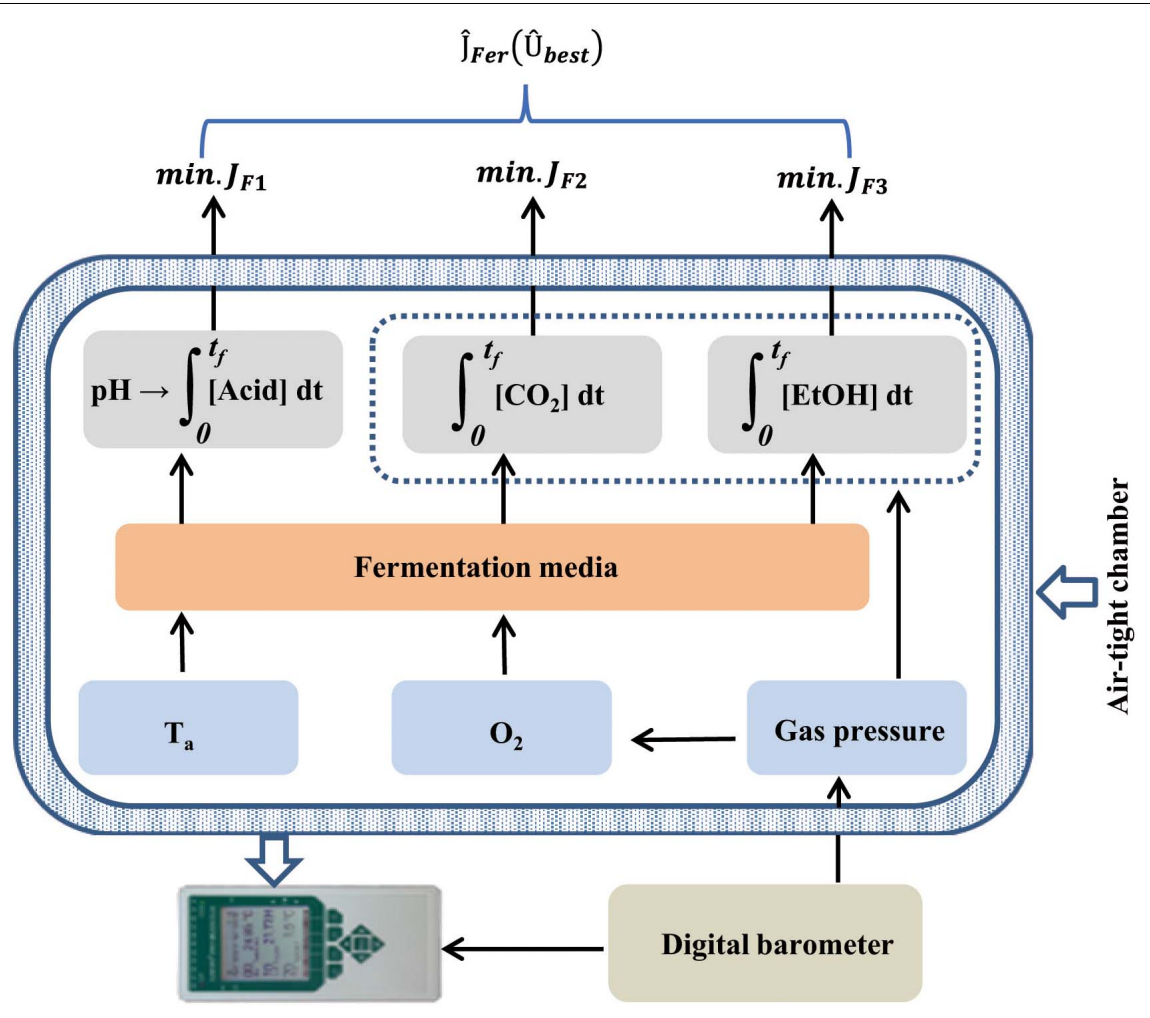

Data-logger

FIGURE 1 | The multi-parameter measurement system devised for selecting microbes used as silage inoculant, based on the characteristics of lactic acid bacterial (LAB) fermentation and the theory of optimal control.

TABLE 1 | Technical information of the $\mathrm{pH}, \mathrm{CO}_{2}$, ethanol (EtOH), $\mathrm{O}_{2}$, temperature, and pressure sensors used.

\begin{tabular}{|c|c|c|c|c|c|}
\hline Parameter & Sensor-type & Manufacturer & Range & Accuracy & Response(s) \\
\hline $\mathrm{pH}$ & BlueLine 21 & SI Analytic GmbH, Germany & $2-13$ & \pm 0.3 & $<20$ \\
\hline Carbon dioxide & Prime 2 & Clairair Ltd., United Kingdom & $0-5 \%$ (vol.) & $\pm 3 \%$ of full scale & $<60$ \\
\hline Ethanol & TGS2610 & Figaro USA, Inc. & $\begin{array}{l}\text { 500-10,000 } \\
\text { (ppm) }\end{array}$ & $\pm 10 \%$ of final value in range & $<300$ \\
\hline \multirow[t]{2}{*}{ Oxygen } & OXROB10 & Pyro Science GmbH, Germany & $\begin{array}{l}\text { Gas phase: } \\
0-100 \% \text { (vol.) }\end{array}$ & Gas phase: $\pm 0.2 \%$ & Gas phase: $<7$ \\
\hline & & & $\begin{array}{l}\text { Dissolved } \\
\text { oxygen:0- } \\
44 \text { mg/L }\end{array}$ & $\begin{array}{l}\text { Dissolved } \\
\text { oxygen: } \pm 0.1 \mathrm{mg} / \mathrm{L}\end{array}$ & Dissolved oxygen: $<15$ \\
\hline Temperature & $\begin{array}{l}\text { FTA15 NiCr-Ni } \\
\text { ZA9020FS }\end{array}$ & $\begin{array}{l}\text { Ahlborn Mess-und } \\
\text { Regelungstechnik GmbH, } \\
\text { Germany }\end{array}$ & -50 to $200^{\circ} \mathrm{C}$ & $\pm 0.1^{\circ} \mathrm{C}$ & 1.5 \\
\hline Atmospheric pressure & FDAD12SA & $\begin{array}{l}\text { Ahlborn Mess-und } \\
\text { Regelungstechnik GmbH, } \\
\text { Germany }\end{array}$ & $\begin{array}{l}700- \\
1,050 \text { (mbar) }\end{array}$ & $\begin{array}{l} \pm 0.5 \% \text { of final value in } \\
\text { range }\end{array}$ & $<5$ \\
\hline Gas pressure & FDA612SR & $\begin{array}{l}\text { Ahlborn Mess-und } \\
\text { Regelungstechnik } \mathrm{GmbH} \text {, } \\
\text { Germany }\end{array}$ & $\pm 1,000$ (mbar) & $\begin{array}{l} \pm 0.5 \% \text { of final value in } \\
\text { range }\end{array}$ & $<5$ \\
\hline
\end{tabular}

fermentation diffuses out of the centrifuge tube through six holes (diameter $2 \mathrm{~mm}$ ) in the wall of the upper tube. Because $\mathrm{CO}_{2}$ is unreactive with $\mathrm{EtOH}$, this allows the glass jar to act as a dual integrator for simultaneous collection of the $\mathrm{CO}_{2}$ and the volatile $\mathrm{EtOH}$ from the fermentation process in the centrifuge tube. The $\mathrm{O}_{2}$ sensor can be moved vertically to measure the $\mathrm{O}_{2}$ concentration in the gas space or $\mathrm{O}_{2}$ dissolved in the medium. To remove $\mathrm{O}_{2}$ for anaerobic requirements, paired holes (diameter $3 \mathrm{~mm}$ ) were perforated in the lid (Figure 2B) for purging with $\mathrm{N}_{2}$. Three sets of the MSMB provided replication for simultaneous 


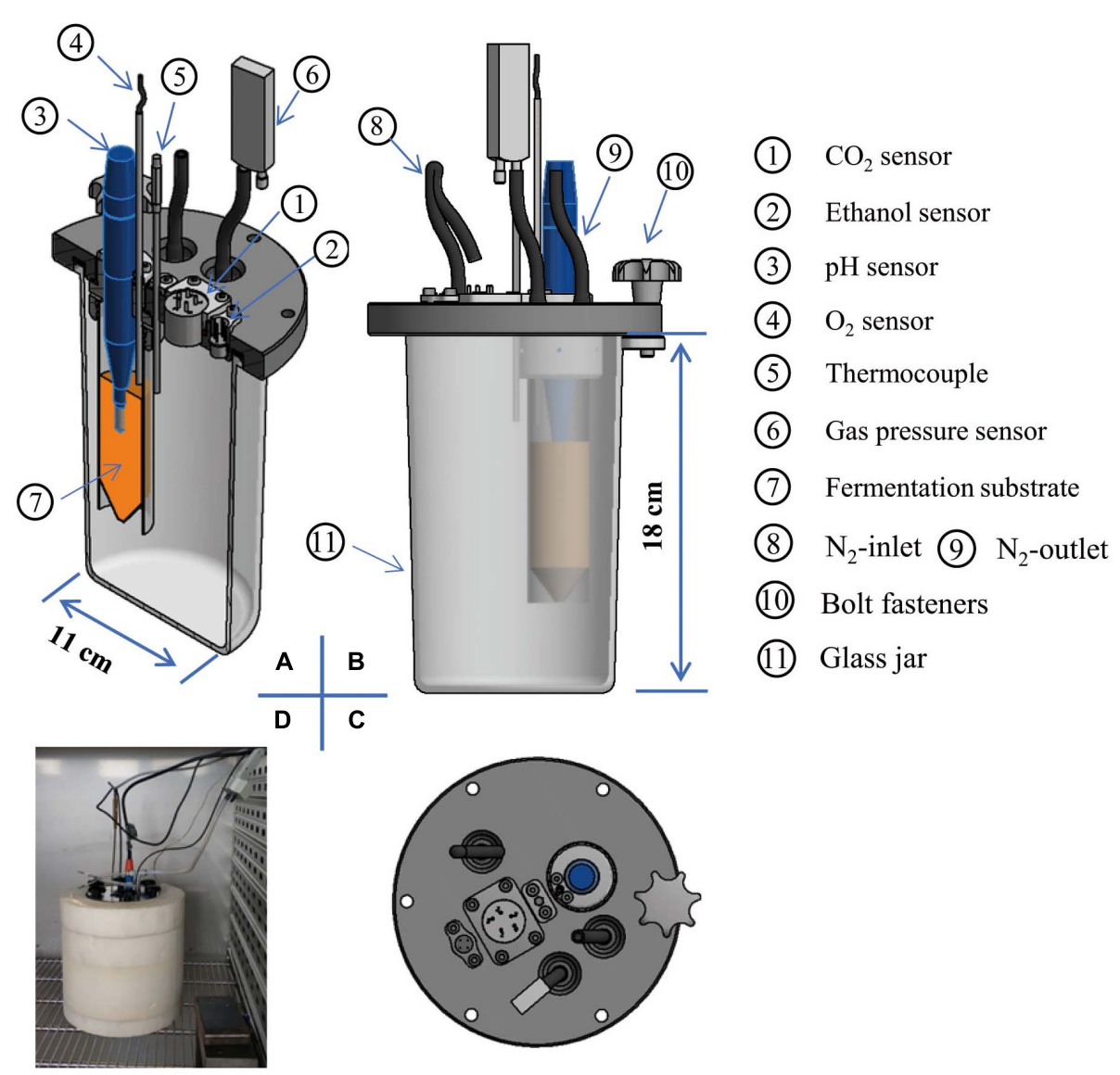

FIGURE 2 | A novel multi-sensor jar, manufactured according to Figure 1, is shown in cross section (A), front view (B), and top view (C) and measured in situ in the incubator (D).

testing. Three data loggers were linked to (i) the thermocouples and $\mathrm{pH}$ electrodes (ALMEMO-2890-9, nine-channel, Ahlborn Mess-und Regelungstechnik $\mathrm{GmbH}$, Ilmenau, Germany), (ii) $\mathrm{CO}_{2}$ and EtOH sensors (own manufacture, eight-channel), and (iii) the $\mathrm{O}_{2}$ sensor (four-channel, Pyro Science $\mathrm{GmbH}$, Aachen, Germany), all sampled at 10-min intervals.

\section{Sample Preparation}

Strains of typical species of obligate heterofermentative bacteria, Lt. buchneri DSM 13573 (LB) and two typical species of facultative heterofermentative bacteria, Lp. plantarum DSM 3676, Lp. plantarum DSM 3677, and Enterococcus faecium NCIMB 11181 (EF), were chosen for the experiment. The two strains of $L b$. plantarum were used as a mixture (1:1) in all experiments and designated as LP. Lt. buchneri DSM 13573 (LB) was used individually and mixed with Lp. plantarum DSM 3676/DSM 3677 (LBLP) or with E. faecium NCIMB 11181 (LBEF).

All candidate bacteria were prepared as lyophilizates by cultivating the strains on synthetic medium and harvesting the cells by centrifugation. The harvested biomass was lyophilized at $-40^{\circ} \mathrm{C}$ for 2 days; and the lyophilizates were stored at $-18^{\circ} \mathrm{C}$. The cell density of the lyophilized LB was $1.6 \times 10^{12} \mathrm{CFU} / \mathrm{g}$.
As $0.1 \mathrm{~g}$ of the lyophilized LB with $40 \mathrm{ml}$ of De Man, Rogosa, and Sharpe (MRS) (Table 2) was cultured during the experiment, the resulting inoculum density of LB was $4 \times 10^{9} \mathrm{CFU} / \mathrm{ml}$. For LBLP and LBEF, either Lp. plantarum DSM 3676/DSM 3677 or E. faecium NCIMB 11181 was added with $10 \%$ of the cell density of the LB (i.e., $4 \times 10^{8} \mathrm{CFU} / \mathrm{ml}$ ). The cell density of the lyophilized LP was $1 \times 10^{11} \mathrm{CFU} / \mathrm{g}$, and that of the lyophilized $\mathrm{EF}$ was $3 \times 10^{12} \mathrm{CFU} / \mathrm{g}$. Thus, $0.160 \mathrm{~g}$ of the lyophilized LP and $0.005 \mathrm{~g}$ of the lyophilized EF were mixed with $0.1 \mathrm{~g}$ of the lyophilized LB. These microbial samples, in $40 \mathrm{ml}$ of sterile MRS broth in each centrifuge tube (vol. $50 \mathrm{ml}$ ), were incubated inside the multi-sensor instrumented jar at $30^{\circ} \mathrm{C}$ for $48 \mathrm{~h}$.

\section{Chemical Analyses}

All the fermented samples were frozen in the centrifuge tubes at $-20^{\circ} \mathrm{C}$ immediately after incubation, prior to chemical analyses. The fermentation acids (lactic and acetic), EtOH, and propanediol were determined using highperformance liquid chromatography (HPLC; KNAUER Azura, Wissenschaftliche Geräte $\mathrm{GmbH}$, Berlin, Germany), coupled with integrated UV and refractive index (RI) detectors as described by Shan et al. (2019). 
TABLE 2 | Composition of the De Man, Rogosa, and Sharpe (MRS) broth.

\begin{tabular}{|c|c|c|c|c|c|}
\hline Substance & Con. & Substance & Con. & Substance & Con. \\
\hline Peptone & $10 \mathrm{~g} / \mathrm{l}$ & Yeast extract & $4 \mathrm{~g} / \mathrm{l}$ & Dipotassium phosphate & $2 \mathrm{~g} / \mathrm{l}$ \\
\hline Glucose & $20 \mathrm{~g} / \mathrm{l}$ & Sodium acetate & $5 \mathrm{~g} / \mathrm{l}$ & Ammonium citrate & $2 \mathrm{~g} / \mathrm{l}$ \\
\hline Beef extract & $8 \mathrm{~g} / \mathrm{l}$ & Polysorbate 80 & $1 \mathrm{~g} / \mathrm{l}$ & Magnesium sulfate $\left(\mathrm{MgSO}_{4}\right)$ & $0.2 \mathrm{~g} / \mathrm{l}$ \\
\hline
\end{tabular}

MRS, De Man, Rogosa, and Sharpe.

\section{Signal Processing}

\section{Normalized Productions of $\overline{\mathrm{CO}_{2}}$ and $\overline{\mathrm{EtOH}}$}

To compare the relative rate of increase of the $\mathrm{CO}_{2}$ or $\mathrm{EtOH}$ in the fermentation process, the normalized productions of carbon dioxide $\left(\overline{\mathrm{CO}_{2}}\right)$ and $\overline{\mathrm{EtOH}}$ were calculated, respectively, as

$$
\overline{\mathrm{CO}_{2}(t)}=\frac{\int_{0}^{t}\left[\mathrm{CO}_{2}\right] d t}{\int_{0}^{t_{f}}\left[\mathrm{CO}_{2}\right] d t} \quad 0 \leq t \leq t_{f}
$$

and

$$
\overline{\operatorname{EtOH}(t)}=\frac{\int_{0}^{t}[\mathrm{EtOH}] d t}{\int_{0}^{t_{f}}[\mathrm{EtOH}] d t} \quad 0 \leq t \leq t_{f}
$$

where both $\overline{\mathrm{CO}_{2}}$ and $\overline{\mathrm{EtOH}}$ vary from 0 to 1 as functions of $t$.

\section{Temporal Rate of $\Delta \mathrm{CO}_{2}$ and $\Delta \mathrm{EtOH}$}

This differential variable may reflect the dynamics of metabolic activity of microorganisms. As sequences of discrete-time data, the differentials of $\mathrm{CO}_{2}$ and $\mathrm{EtOH}$ were calculated over time as

$$
\left.\begin{array}{c}
\triangle \mathrm{CO}_{2}=\left[\mathrm{CO}_{2}\left(t_{i}\right)\right]-\left[\mathrm{CO}_{2}\left(t_{i-1}\right)\right] \\
\triangle \mathrm{EtOH}=\left[\mathrm{EtOH}\left(t_{i}\right)\right]-\left[\mathrm{EtOH}\left(t_{i-1}\right)\right] \\
t_{0}=0, t_{n}=t_{f}, i=1,2, \ldots . n
\end{array}\right\}
$$

\section{Signal Decomposition}

Signal decomposition, a function of smart instruments, is often used to partition a mixed source signal into its constitutive pure components for various engineering problems (Li et al., 2013; Shan et al., 2019). In this study, the fermentation characteristics relative to different strains or combinations are regarded as mathematical curves in functional space. Three time courses of $\mathrm{pH}$ (i.e., $\mathrm{pH}_{L B}, \mathrm{pH}_{L B L P}$, and $\mathrm{pH}_{L B E F}$ ) are directly tracked in situ from the experiment. Through data decomposition, $\mathrm{pH}_{L P}$ and $\mathrm{pH}_{E F}$ can also be obtained, such that

$$
\left.\begin{array}{l}
\mathrm{pH}_{\mathrm{LP}}(t)=\mathrm{pH}_{0}+\left(\mathrm{pH}_{\mathrm{LBLP}}(t)-\mathrm{pH}_{\mathrm{LB}}(t)\right) \\
\mathrm{pH}_{\mathrm{EF}}(t)=\mathrm{pH}_{0}+\left(\mathrm{pH}_{\mathrm{LBEF}}(t)-\mathrm{pH}_{\mathrm{LB}}(t)\right)
\end{array}\right\}
$$

where $\mathrm{pH}_{0}$ is the initial value of each substrate.

\section{Statistical Analysis}

The experimental data were analyzed using IBM SPSS v25.0 (IBM Co., Armonk, NY, United States). Linear regression, curve fitting, and fitting errors were evaluated using coefficient of determination $\left(R^{2}\right)$ and root mean square error (RMSE). Two-way analysis of variance (ANOVA) was conducted for effects of the experimental scheme (two air environments, i.e., anaerobic and aerobic), treatment (three types, i.e., LB, LBEF, and LBLP), and the interactions of the chemical compositions for the final-data processing. One-way ANOVA was used to evaluate the statistical significance among anaerobic and aerobic environments.

\section{RESULTS}

\section{Acidification Characteristics}

Two sets of time courses of $\mathrm{pH}$ (Figure 3), each with respect to the mean of three replicates, were recorded in situ from the fermentation process in the MSMB, the first set (Figure 3A) from anaerobic fermentation and the second set (Figure 3B) from aerobic fermentation. The patterns observed were similar. Figure 4 shows the time courses of $\mathrm{O}_{2}$ concentration over the experiment with two parts, i.e., as liquid phase dissolved in the MRS and as gaseous phase distributed in the glass jars. When comparing the anaerobic fermentation (Figure 4A) and aerobic one (Figure 4B), the amounts of gaseous oxygen in these jars remained two constant levels throughout the experiment, i.e., around $0.2 \mathrm{vol}$. \% of $\mathrm{O}_{2}$ concentration in the anaerobic jars and 20 vol. \% of $\mathrm{O}_{2}$ concentration in the aerobic jars. The $\mathrm{O}_{2}$ dissolved in the MRS in both anaerobic and aerobic jars varied with similar trends in the initial $5 \mathrm{~h}$, i.e., declined from 0.157 to $0.138 \mathrm{mg} / \mathrm{L}$, and then reached a plateau. This and the chemical analyses from aerobic and anaerobic fermentations at the end of the experiment (Table 3) demonstrate that the oxygen in the MSMB had minimal impact on the respiratory metabolism of the microbes tested.

In general, all time courses of $\mathrm{pH}$ (Figures $\mathbf{3 A}, \mathbf{B}$ ), i.e., the acidification characteristics, were well described by exponential regressions, in both anaerobic and aerobic fermentations. The steepest decline was observed from the LBLP $\left(\mathrm{pH}_{L B L P}=5\right.$, $t=4.5 \mathrm{~h}$, anaerobic), evidently faster than that of LBEF $\left(\mathrm{pH}_{L B E F}=5, t=10 \mathrm{~h}\right.$, anaerobic) or that of the $\mathrm{LB}\left(\mathrm{pH}_{L B}=5\right.$, $t=11.5 \mathrm{~h}$, anaerobic). Additionally, the $\mathrm{pH}_{L B L P}$ had the lowest values $\left(\mathrm{pH}_{L B L P}=3.61\right.$ or 3.65$)$ in both anaerobic and aerobic fermentations, which agreed with the finding that the contents of lactic acid in the fermented MRS of LBLP are slightly higher than those of LB and LBEF (Table 3).

The final time $\left(t_{f}\right)$ was determined as $\mathrm{pH} \leq 4$ over six consecutive measurements (i.e., $1 \mathrm{~h}$ ). The $t_{f}$ of the $\mathrm{pH}_{L B L P}$ was only $12 \mathrm{~h}$, whereas the $t_{f}$ for both $\mathrm{pH}_{L B E F}$ and $\mathrm{pH}_{L B}$ was more than double at $28 \mathrm{~h}$. Therefore, for these microbial samples in the same experimental conditions, the acidification characteristics of the LBLP had the lowest $t_{f}$ (i.e., the fastest process). Therefore, the resulting time course of $\mathrm{pH}_{L B L P}$ is time optimal, but this only fulfilled by one of the two necessary criteria for a global 

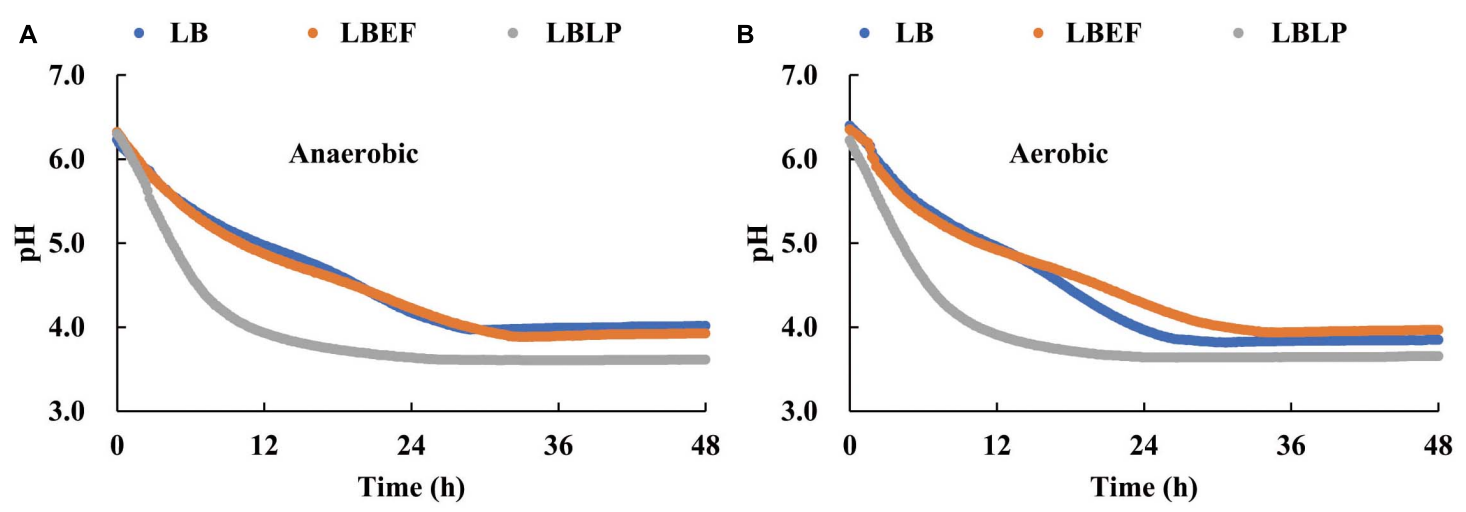

\begin{tabular}{|llllll|}
\hline \multicolumn{6}{|c|}{$\mathrm{y}=\mathrm{ae}^{-\mathrm{bx}}+\mathrm{c}$} \\
\hline & $\mathrm{a}$ & $\mathrm{b}$ & $\mathrm{c}$ & $\mathrm{R}^{2}$ & RMSE \\
\hline LB & 3.518 & 0.032 & 2.583 & 0.994 & 0.049 \\
LBEF & 2.762 & 0.052 & 3.425 & 0.994 & 0.050 \\
LBLP & 2.961 & 0.172 & 3.580 & 0.996 & 0.049 \\
\hline
\end{tabular}

\begin{tabular}{|llllll|}
\hline \multicolumn{6}{|c|}{$\mathrm{y}=\mathrm{ae}^{-\mathrm{bx}}+\mathrm{c}$} \\
\hline & $\mathrm{a}$ & $\mathrm{b}$ & $\mathrm{c}$ & $\mathrm{R}^{2}$ & RMSE \\
\hline LB & 3.719 & 0.039 & 2.582 & 0.994 & 0.059 \\
LBEF & 2.652 & 0.056 & 3.567 & 0.988 & 0.071 \\
LBLP & 2.818 & 0.174 & 3.585 & 0.997 & 0.040 \\
\hline
\end{tabular}

FIGURE 3 | Three time courses of the acidification process with respect to Lentilactobacillus buchneri (LB), LB mixed with Enterococcus faecium (LBEF), and LB mixed with Lactiplantibacillus plantarum (LBLP), under anaerobic (A) and aerobic conditions (B). LB, Lentilactobacillus buchneri; LBEF, LB mixed with Enterococcus faecium; LBLP, LB mixed with Lactiplantibacillus plantarum.
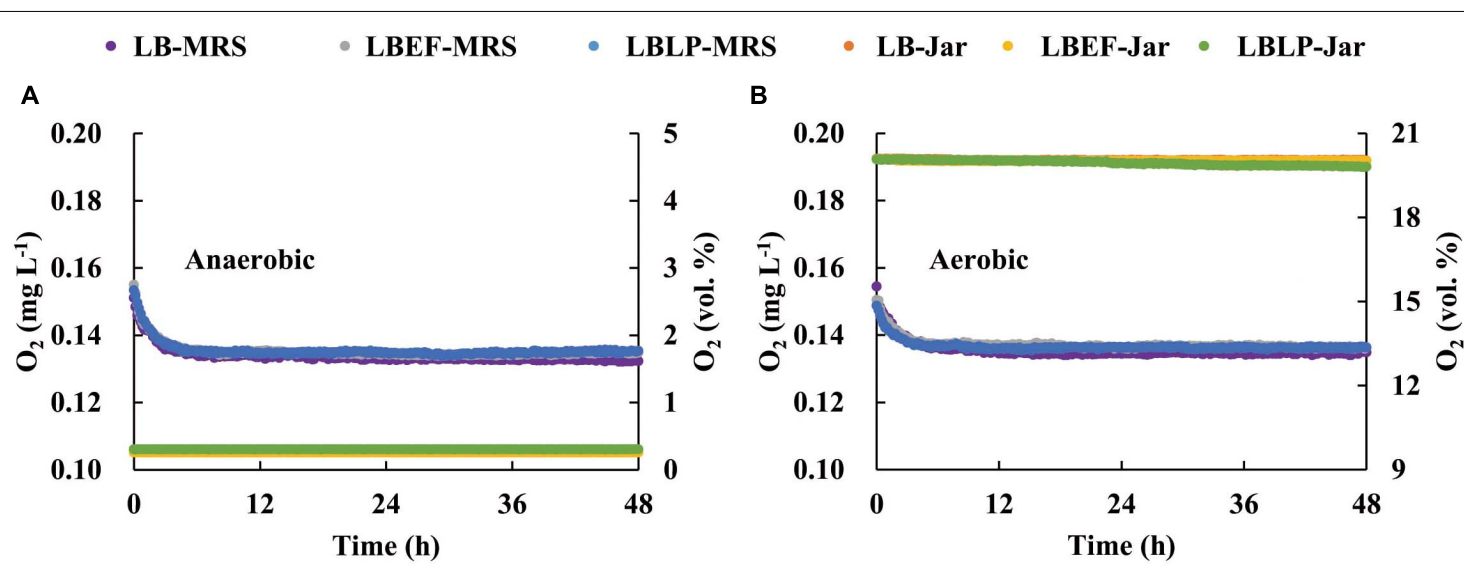

FIGURE 4 | Time courses of $\mathrm{O}_{2}$ concentration dissolved in the De Man, Rogosa, and Sharpe (MRS) and distributed in the sealed jars during the anaerobic (A) and aerobic (B) fermentations. MRS, De Man, Rogosa, and Sharpe.

TABLE 3 | Final chemical analyses of the three types of samples.

\begin{tabular}{|c|c|c|c|c|c|c|c|c|c|c|}
\hline Variable & \multicolumn{3}{|c|}{ Anaerobic } & \multicolumn{3}{|c|}{ Aerobic } & SEM & \multicolumn{3}{|c|}{ Significance of effects } \\
\hline $\mathrm{pH}$ & $4.06^{a}$ & $4.07^{\mathrm{a}}$ & $3.61^{\mathrm{b}}$ & $4.10^{\mathrm{A}}$ & $3.96^{\mathrm{A}}$ & $3.65^{\mathrm{B}}$ & 0.048 & NS & $\star *$ & NS \\
\hline Lactic acid (g/l) & 13.56 & 12.23 & 16.44 & 12.77 & 13.52 & 15.33 & 1.238 & NS & NS & NS \\
\hline Acetic acid (g/l) & 5.74 & 5.27 & 4.82 & 5.78 & 6.08 & 4.66 & 0.420 & NS & NS & NS \\
\hline Ethanol (g/l) & $3.36^{a}$ & $1.81^{\mathrm{b}}$ & $1.08^{\mathrm{C}}$ & $3.47^{\mathrm{A}}$ & $1.95^{\mathrm{B}}$ & $1.00^{C}$ & 0.133 & NS & $\star *$ & NS \\
\hline
\end{tabular}

SEM, standard error of the mean; $A$, air environment (anaerobic or aerobic); $T$, treatment (LB, LBEF, or LBLP).

LB, Lentilactobacillus buchneri; LBEF, LB mixed with Enterococcus faecium; LBLP, LB mixed with Lactiplantibacillus plantarum; NS, not significant.

${ }^{* *} p<0.01$.

$a-c, A-C$ Means with different superscripts within the same air environment differ significantly $(p<0.05)$. 


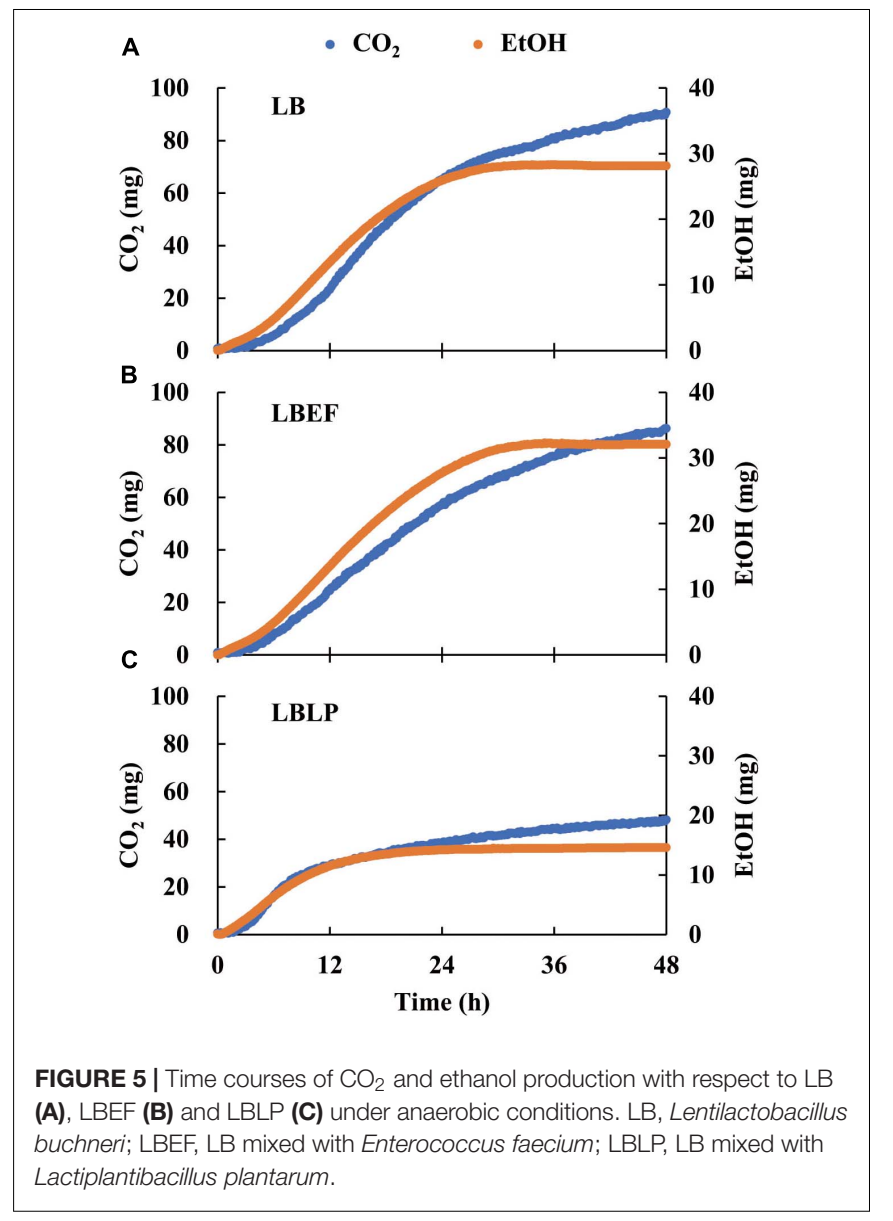

optimal solution of the Bolza equation (i.e., the term of min. $\left(t_{f}-\right.$ $\left.t_{0}\right)_{p H \downarrow}$ in Eq. 3).

\section{Formations of $\mathrm{CO}_{2}$ and EtOH}

Three time courses of $\mathrm{CO}_{2}$ and $\mathrm{EtOH}$ formation (Figure 5) were recorded from the LB (A), the LBEF (B), and the LBLP (C). The fermentation governed by the LBLP yielded the lowest $\mathrm{CO}_{2}(48.12 \mathrm{mg})$ and EtOH $(14.55 \mathrm{mg})$ in the period of $48 \mathrm{~h}$. In contrast, the fermentation with the LB or the LBEF yielded more than twice as much $\mathrm{CO}_{2}(86.21-90.72 \mathrm{mg})$ and $\mathrm{EtOH}(28.14-$ $32.10 \mathrm{mg})$. Figure 6 shows the normalized $\mathrm{CO}_{2}$ production $\left(\overline{\mathrm{CO}_{2}}\right.$, Figure 6A) and $\overline{\mathrm{EtOH}}$ (Figure 6B) from the three samples. For the LBLP, the $\overline{\mathrm{CO}_{2}}$ reached 0.8 of the final production in $24.5 \mathrm{~h}$, while the $\overline{\mathrm{CO}_{2}}=0.8$ for the LB was $28 \mathrm{~h}$ or for the LBEF was $31 \mathrm{~h}$. Similarly, the transition times of $\overline{\mathrm{EtOH}}$ increased to 0.8 for the LBLP, LB, and LBEF at 12.3, 19.5, and $21.8 \mathrm{~h}$, respectively. In contrast, the rate of EtOH increase was greater than that of $\mathrm{CO}_{2}$ in all the samples.

\section{Metabolic Sensitivity to $\mathbf{p H}$}

Figure 7 shows stepwise tracing $\left(t_{i}-t_{i-1}=2 \mathrm{~h}\right.$, Eq. 6) for the temporal production of both $\mathrm{CO}_{2}$ and EtOH. In the initial period of fermentation $(\mathrm{pH}>5)$, the increasing $\Delta \mathrm{CO}_{2}$ and $\triangle \mathrm{EtOH}$ reflected the increasing microbial activity for all microbes. A turning point of $\Delta \mathrm{CO}_{2}$ and $\Delta \mathrm{EtOH}$ occurred around $\mathrm{pH} 5$. Below $\mathrm{pH} 5$, the metabolic activity decreased as the $\mathrm{pH}$ declined. After the $\mathrm{pH}$ declined to 4 , both $\Delta \mathrm{CO}_{2}$ and $\Delta \mathrm{EtOH}$ reached minima and then achieved steady state. The patterns in Figure 7 not only characterize the metabolic sensitivity of these microbes to $\mathrm{pH}$ but also contain the dynamic information of the acidification process from each sample. For the LBLP sample, $\mathrm{pH}_{L B L P}$ decreased to 5 in less time $(4.5 \mathrm{~h})$, resulting in only three data points of $\Delta \mathrm{CO}_{2}\left(t_{i}-t_{i-1}=2 \mathrm{~h}\right)$ while $\mathrm{pH} \geq 5$. In contrast, seven data points of $\triangle \mathrm{CO}_{2}$ for $\mathrm{LB}$ and $\mathrm{LBEF}$ were recorded due to the longer periods of $\mathrm{pH} \geq 5\left(\mathrm{pH}_{L B}, 11.5 \mathrm{~h} ; \mathrm{pH}_{L B E F}\right.$, $10 \mathrm{~h}$ ). The patterns of EtOH (Figures 7B,D) had similar temporal implications. Because the turning points of $\Delta \mathrm{CO}_{2}$ and $\Delta \mathrm{EtOH}$ at $\mathrm{pH} 5$ correlated for all the microbial samples (Figure 7), the general effect of $\mathrm{pH}$ on the metabolic activity can be estimated. Figure 8 presents four piecewise linear regressions corresponding to $\Delta \mathrm{CO}_{2}$ (Figure $\mathbf{8 A ~} \mathrm{pH}<5$, Figure $\mathbf{8 B} \mathrm{pH}>5$ ) and $\Delta \mathrm{EtOH}$ (Figure 8C pH $<5$, Figure 8D $\mathrm{pH}>5$ ), related to the three microbial samples.

\section{Role Partition of Each Strain}

In functional space, the time courses of both $\mathrm{pH}_{L B L P}$ and $\mathrm{pH}_{L B E F}$ (Figure 3) are mathematically decomposable in relation to the time course of $\mathrm{pH}_{L B}$. With the use of Eq. 7 together with the time course of $\mathrm{pH}_{L B}$ (Figure 3) as reference, Figure 9 shows these separate time courses for $\mathrm{pH}_{L P}$ and $\mathrm{pH}_{E F}$ over the initial $12 \mathrm{~h}$ of the fermentation. We presented the decomposed data in the early stage $(0-12 \mathrm{~h})$ because $\mathrm{pH}_{L B L P}$ reached a plateau within $12 \mathrm{~h} \leq t \leq 48 \mathrm{~h}$ (Figure 3). The regression demonstrated that the LP species played an exponentially accelerating role $\left(\mathrm{R}^{2}=0.982\right.$, RMSE $\left.=0.053\right)$ in the acidification process over $\mathrm{pH}$ ranging from 6.23 to 5.0. The major contribution of LP to the fermentation process was observed in the initial period of $0-6$ h, i.e., $\mathrm{pH} \geq 5.5$. Subsequently, the accelerating role of the LP attenuated quickly as the $\mathrm{pH}$ decreased, and this could be attributed to the stronger suppression from the increasing organic acid in the fermentation medium. Alternatively, the separate role of the EF is a straight line, perpendicular to the $\mathrm{pH}$ axis at the initial point $\left(\mathrm{pH}_{0}=6.23\right)$. This demonstrates that the role of the $\mathrm{EF}$ in accelerating the acidification process is negligible, not an optimal solution for Eq. 3.

\section{DISCUSSION}

Both the shortest acidification process (min. $t_{f}$ in section "Acidification Characteristics") and the minimum gas production (see section "Formations of $\mathrm{CO}_{2}$ and $\mathrm{EtOH}$ ") resulted from the LBLP, and therefore, this is a time-energy optimal fermentation reaction (Sargent, 2000). Moreover, the time course of $\mathrm{pH}_{L B L P}$ (Figure 3) is the optimal trajectory of the fermentation process, and the exponential equation of the LP (Figure 9) is the optimal control function $\left(\mathrm{u}_{m-\text { best }}\right)$ determined. The paired optimal solutions were found experimentally and subject to the Bolza equation (Eq. 3) (Clarke, 1976).

As expected, lactic acid was the primary metabolite of LAB fermentation (Table 3). Our experimental data 

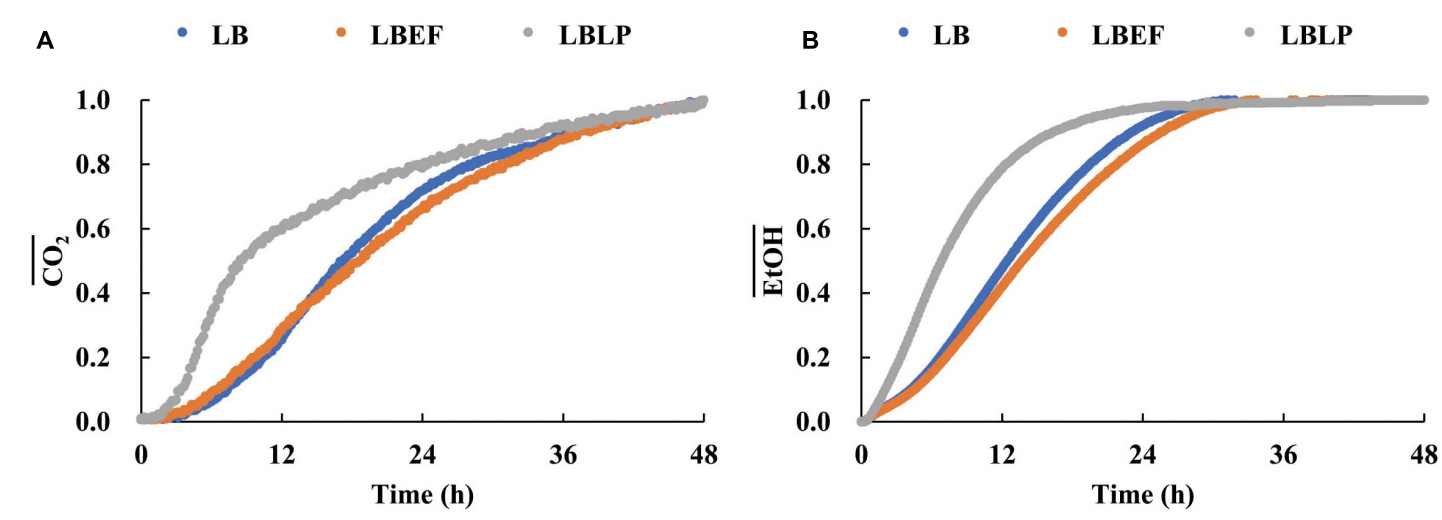

FIGURE 6 | Relative variations of $\mathrm{CO}_{2} \mathbf{( A )}$ and $\mathrm{EtOH}(\mathbf{B})$ productions of the three samples.
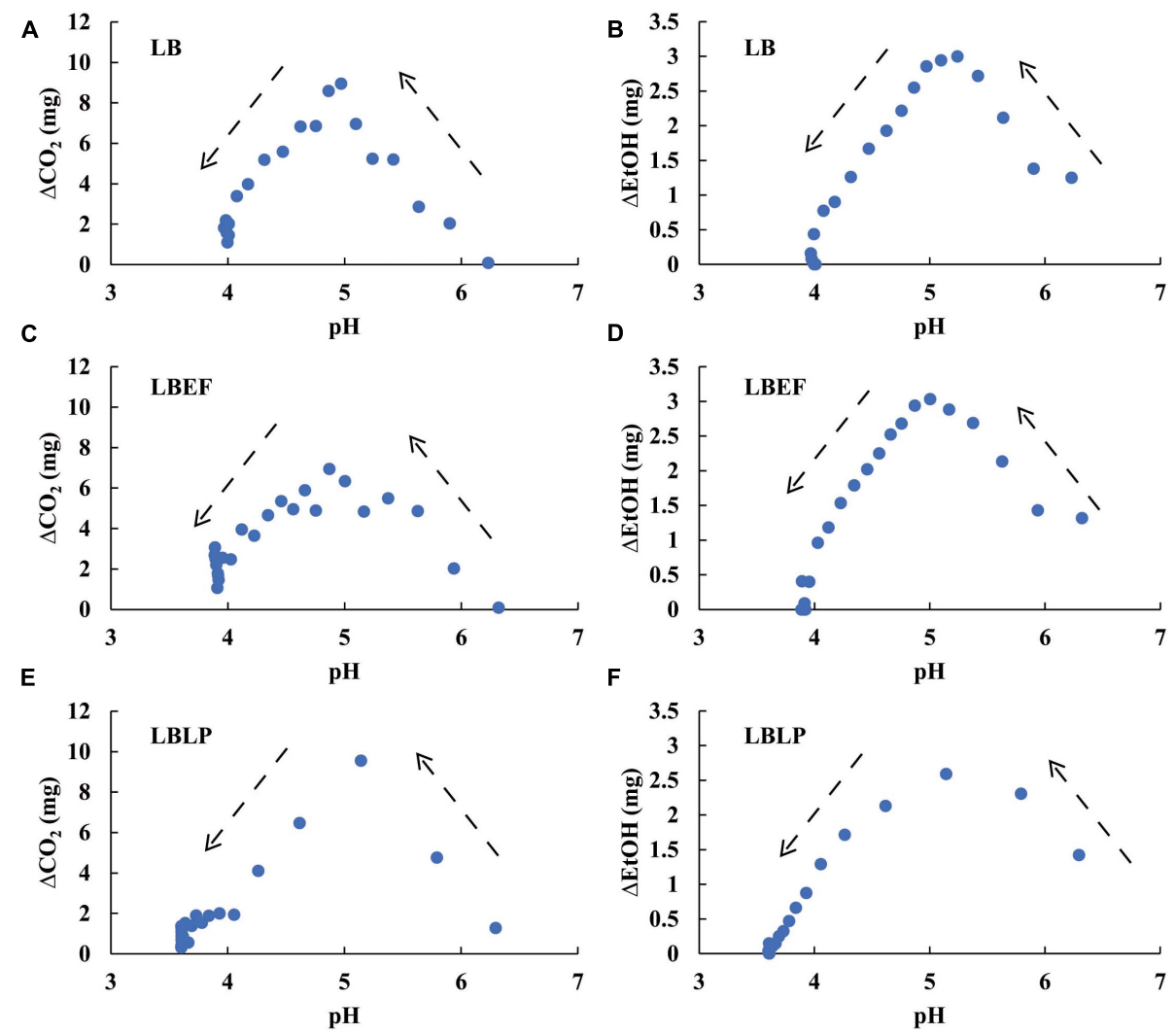

FIGURE 7 | The relationships between the $\mathrm{pH}$ of the three microbial samples and the differential variables of both $\mathrm{CO}_{2}$ production (A,C,E) and EtOH production (B,D,F), where $\Delta \mathrm{CO}_{2}=\mathrm{CO}_{2}\left(t_{i}\right)-\mathrm{CO}_{2}\left(t_{i-1}\right)$ and $\Delta \mathrm{EtOH}=\mathrm{EtOH}\left(t_{i}\right)-\mathrm{EtOH}\left(t_{i-1}\right)$, both calculated with $t_{i}-t_{i-1}=2 \mathrm{~h}, i=0,1, \ldots, n$. The arrows denote the time course of decreasing $\mathrm{pH}$.

supported the hypothesis that $\mathrm{pH}$ was primarily dominated by variations in lactic acid during the $\mathrm{LAB}$ fermentation process (Kung et al., 2018a) from two notes: (i) the $L p$. plantarum strains DSM 3676 and DSM 3677 (LP), the facultative heterofermentative strains, played a major role in producing lactic acid during the initial $0-6 \mathrm{~h}$ of the fermentation (Figures 3, 9). At $t=6 \mathrm{~h}$, the $\mathrm{pH}_{L B L P}=4.62$ indicated that most lactic acid had already been formed. (ii) The pKa of acetic acid (4.75) is higher than that of lactic acid (3.86), reflecting it being a 10 times weaker acid than lactic acid (Danner et al., 2003; Graves et al., 2006; Kung et al., 2018a).

Our data of the relationship between $\mathrm{CO}_{2}$ and $\mathrm{pH}$ (Figures 7,8) support a value of $\mathrm{pH} 5$ as a critical value governing microbial growth, with rapid $(\mathrm{pH}>5)$ or slower to no growth $(\mathrm{pH}<5)$ during the ensiling process (Kung et al., 2003; Pahlow et al., 2003). We show this for the first time 

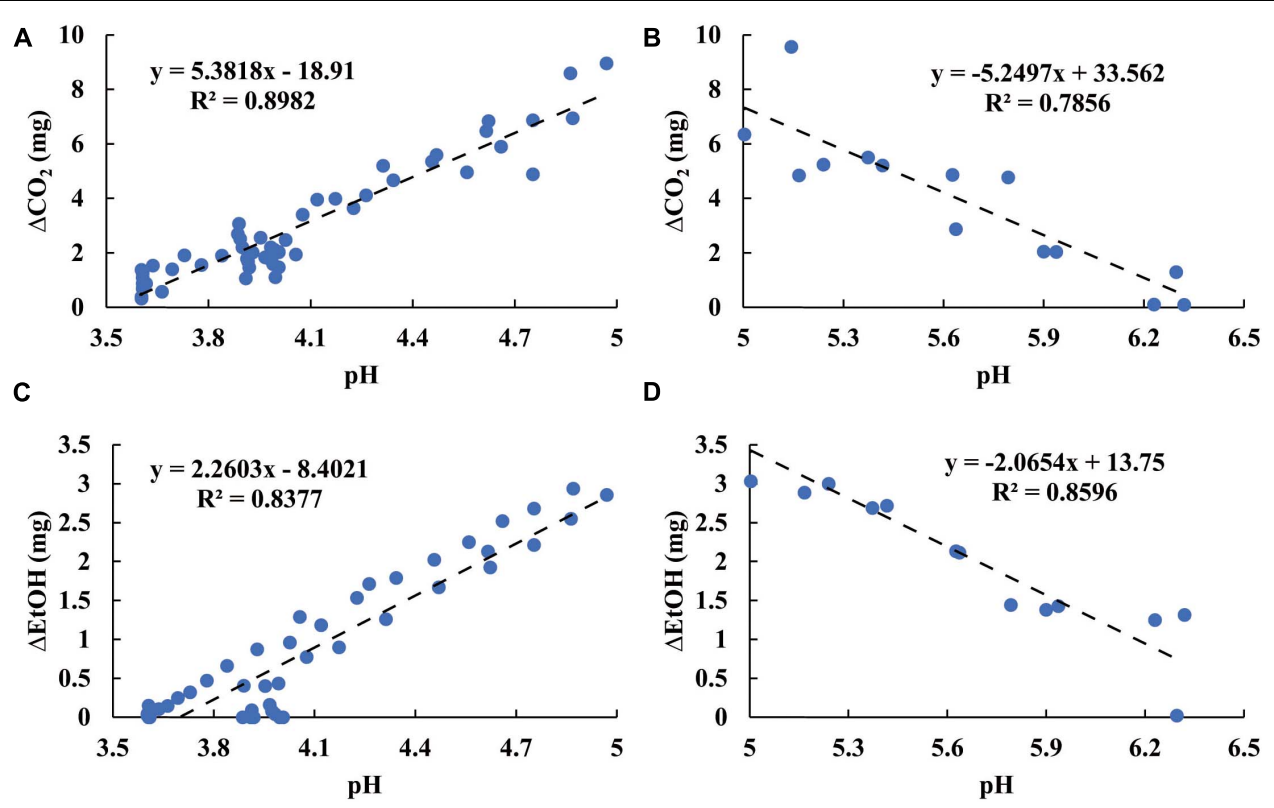

FIGURE 8 | Effect of $\mathrm{pH}$ on the rate of microbial respiration in relation to $\Delta \mathrm{CO}_{2}$ with $\mathrm{pH}<5$ (A), $\Delta \mathrm{CO}_{2}$ with $\mathrm{pH} \geq 5$ (B), $\Delta \mathrm{EtOH}$ with $\mathrm{pH}<5$ (C), and $\Delta \mathrm{EtOH}$ with $\mathrm{pH} \geq 5$ (D).

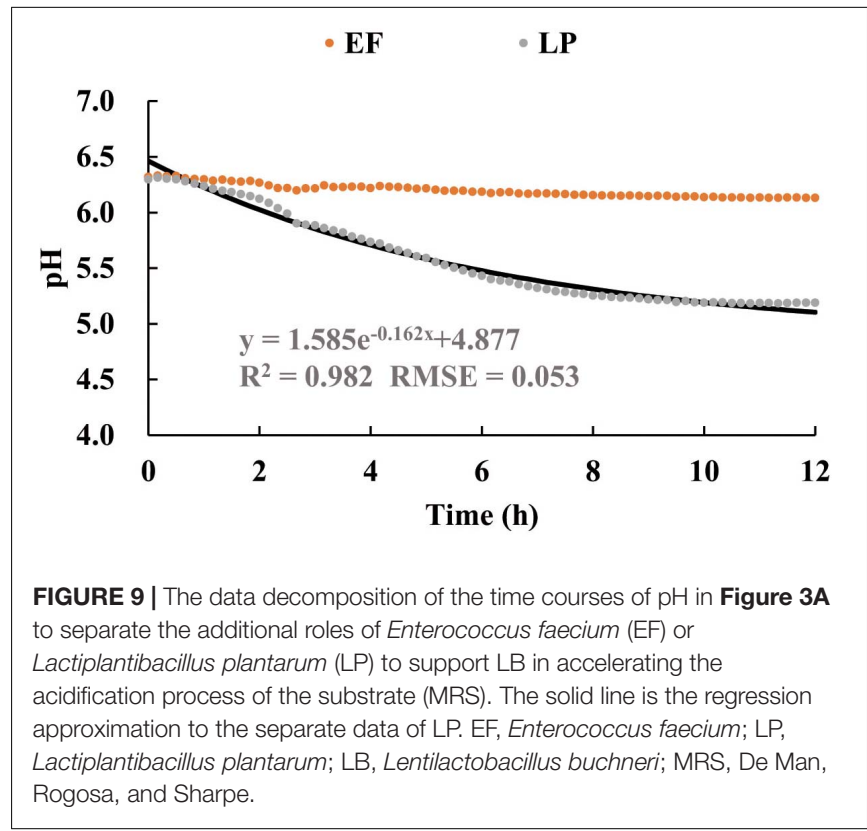

using the dynamics of microbial respiration over the course of fermentation. This had previously been suggested from an ex situ determination of microbial counts (Oliveira et al., 2017). Our in situ method obviates the process of plate-culture counts, which create assessment delays of several days (Wilkinson and Muck, 2019) and may require multiple samplings over time. In contrast to the ex situ method, our MSMB provides both real-time anaerobic measurements of $\mathrm{CO}_{2}$ and $\mathrm{EtOH}$ productions and instantaneous microbial activity.
A few studies tested silage inoculants using MRS broth or the aqueous extract of silage crop (Oude Elferink et al., 2001; Danner et al., 2003; Holzer et al., 2003; Graves et al., 2006; Arasu et al., 2015; Blajman et al., 2020). Fermentation characteristics, such as production of organic acids, decreasing dynamics of $\mathrm{pH}$, and $\mathrm{CO}_{2}$ production, depend on medium composition (Danner et al., 2003; Blajman et al., 2020). The next step of our study is to replace MRS broth with the aqueous extract of silage, creating a testing condition that may be closer to the natural culture of silage ensiling for LAB. However, the effect of the buffering capacity of silage crop on $\mathrm{pH}$ is inherent (Kung et al., 2003; Pahlow et al., 2003; Shan et al., 2021) and should be taken into account. Unfortunately, this effect cannot be evaluated when either MRS broth or the liquid extraction of silage crop is used as fermentation medium.

High concentrations of EtOH are usually attributed to large numbers of yeasts (Kung and Ranjit, 2001; Kung et al., 2018a). However, the silage containing LB (Oude Elferink et al., 2001) produced $\mathrm{EtOH}$ from anaerobic degradation of lactic acid in corn silage. Kung and Ranjit (2001) noted the high EtOH from treated barley silage, but not from the control. The EtOH data of our study from the MRS broth support the previous observations. Moreover, in this study, EtOH was measured in situ as the gaseous concentration in the sealed jar, which by Henry's law is directly proportional to the concentration of $\mathrm{EtOH}$ dissolved in the fermentation medium (Sun et al., 2015). While the partition coefficient of Henry's law is temperature-dependent, the fermentation here was carried out at constant temperature $\left(30^{\circ} \mathrm{C}\right)$.

During the ensiling process, the $\mathrm{CO}_{2}$ recorded in the fermentation phase consists of two parts, one from the initial aerobic phase and one from anaerobic fermentation 
(Li et al., 2017). It is challenging to separate them into two $\mathrm{CO}_{2}$ pools for the different phases (Shan et al., 2019). In this study, the measured $\mathrm{CO}_{2}$ (Figures 5-8) derived completely from anaerobic heterofermentative $\mathrm{LAB}$ fermentation because the MSMB provided a manageable environment between anaerobic and aerobic seals. This is also an advantage of the MSMB over the ensiling experiment with the natural culture of silage.

It is not surprising that Figures $\mathbf{3 A} \mathbf{A} \mathbf{B}$ had similar patterns. Members of the family Lactobacillaceae are anaerobic, but the majority of species are oxygen tolerant to some degree and often completely. Only very few species of LAB were observed to react to $\mathrm{O}_{2}$ (Condon, 1987). On the technical side, Figure 3 demonstrates that the multi-sensor instrument presented here is suitable for both anaerobic and aerobic experiments. Since the aerobic stability of silage refers to a de-acidification process governed by fungus in silage (Wilkinson and Davies, 2012; Kung et al., 2018a), and the aerobic deterioration of silage is commonly associated with changes in temperature, $\mathrm{pH}, \mathrm{CO}_{2}$ production, and $\mathrm{O}_{2}$ consumption (Honig, 1990; Muck and Pitt, 1994; Weinberg and Ashbell, 2003; Sun et al., 2015; Robinson and Swanepoel, 2016), this novel MSMB could also be useful to qualitatively observe the role of acetic acid in inhibiting fungal growth during aerobic phases of silage production.

\section{CONCLUSION}

We have devised an MSMB to facilitate preselection of microbes as silage inoculants. We demonstrate successful screening of the dynamics of the acidification process, gas production, and metabolic activity from the MRS-based LAB fermentation, using in situ simultaneous measurements of $\mathrm{pH}, \mathrm{CO}_{2}$, and $\mathrm{EtOH}$. We have further used this novel information to introduce an optimal control model, using signal decomposition, for selecting candidate microbes. Future studies are planned to evaluate this novel prototype with aqueous extracts of common silage materials during anaerobic LAB fermentation and to extend its applicability to silage aerobic stability.

\section{REFERENCES}

Arasu, M. V., Jung, M. W., Kim, D. H., Park, H. S., Ilavenil, S., Al-Dhabi, N. A., et al. (2015). Identification and phylogenetic characterization of novel Lactobacillus plantarum species and their metabolite profiles in grass silage. Ann. Microbiol. 65, 15-25. doi: 10.1007/s13213-014-0830-2

Blajman, J. E., Vinderola, G., Cuatrin, A., Lingua, M. S., and Páez, R. B. (2020). Technological variables influencing the growth and stability of a silage inoculant based on spray-dried lactic acid bacteria. J. Appl. Microbiol. 129, 1486-1496. doi: $10.1111 /$ jam.14750

Bolsen, K. K., Aschbell, G., and Weinberg, Z. G. (1996). Silage fermentation and silage additives - Review. Asian-Australas. J. Anim. Sci. 9, 483-493. doi: 10. 5713/ajas.1996.483

Borreani, G., and Tabacco, E. (2010). The relationship of silage temperature with the microbiological status of the face of corn silage bunkers. J. Dairy Sci. 93, 2620-2629. doi: 10.3168/jds.2009-2919

Clarke, F. H. (1976). The generalized problem of Bolza. SIAM J. Control Optim. 14, 682-699. doi: 10.1137/0314044

Condon, S. (1987). Responses of lactic acid bacteria to oxygen. FEMS Microbiol. Rev. 46, 269-280. doi: 10.1111/j.1574-6968.1987.tb02465.x

\section{DATA AVAILABILITY STATEMENT}

The original contributions presented in the study are included in the article/supplementary material, further inquiries can be directed to the corresponding author.

\section{AUTHOR CONTRIBUTIONS}

$\mathrm{AM}$ and YS designed the study. WBu, GS, WBe, CM, and YS devised the instrument. GS, VR, YW, and YS performed the experiment. YS designed the mathematical frame. GS and YS designed the data process. GS made the statistical analysis. VR conducted the chemical analysis. GS, AM, AL, DG, and YS wrote the manuscript. All authors contributed to the article and approved the submitted version.

\section{FUNDING}

This study was funded by the German Research Foundation [Deutsche Forschungsgemeinschaft (DFG)] under the projects BU 1235/11-1, 414320577 and BU 1235/13-1, 449744781. GS was funded with the SinoGerman postdoctoral scholarship joined by Deutscher Akademischer Austauschdienst (DAAD) and China Scholarship Council (CSC).

\section{ACKNOWLEDGMENTS}

We thank R. Lutz (working at the Department of Agricultural Engineering, University of Bonn) for his help in our experiment, and we gratefully acknowledge the assistance of Fabian Weber (University of Bonn) and Michael Short in improving an earlier draft of the English text.

Danner, H., Holzer, M., Mayrhuber, E., and Braun, R. (2003). Acetic acid increases stability of silage under aerobic conditions. Appl. Environ. Microbiol. 69, 562567. doi: 10.1128/AEM.69.1.562-567.2003

Graves, T., Narendranath, N. V., Dawson, K., and Power, R. (2006). Effect of pH and lactic or acetic acid on ethanol productivity by Saccharomyces cerevisiae in corn mash. J. Ind. Microbiol. Biotechnol. 33, 469-474. doi: 10.1007/s10295-0060091-6

Holzer, M., Mayrhuber, E., Danner, H., and Braun, R. (2003). The role of Lactobacillus buchneri in forage preservation. Trends Biotechnol. 21, 282-287. doi: 10.1016/S0167-7799(03)00106-9

Honig, H. (1990). "Evaluation of aerobic stability in Grass and forage reports," in Proceedings of the Eurobac Conference, Uppsala, 76-82.

Kung, L., and Ranjit, N. K. (2001). The effect of Lactobacillus buchneri and other additives on the fermentation and aerobic stability of barley silage. J. Dairy Sci. 84, 1149-1155. doi: 10.3168/jds.S0022-0302(01)74575-4

Kung, L., Shaver, R. D., Grant, R. J., and Schmidt, R. J. (2018a). Silage review: interpretation of chemical, microbial, and organoleptic components of silages. J. Dairy Sci. 101, 4020-4033. doi: 10.3168/jds.2017-13909

Kung, L., Smith, M. L., da Silva, E. B., Windle, M. C., da Silva, T. C., and Polukis, S. A. (2018b). An evaluation of the effectiveness of a chemical additive based on 
sodium benzoate, potassium sorbate, and sodium nitrite on the fermentation and aerobic stability of corn silage. J. Dairy Sci. 101, 5949-5960.

Kung, L., Stocks, M., and Lin, C. J. (2003). Silage Additives, eds D. R. Buxton, R. E. Muck, and J. H. Harrison (Madison, WI: American Society of Agronomy Inc), 31-93. doi: 10.2134/agronmonogr42.c7

Li, M., Shan, G., Zhou, H., Buescher, W., Maack, C., Jungbluth, K. H., et al. (2017). $\mathrm{CO}_{2}$ production, dissolution and pressure dynamics during silage production: multi-sensor-based insight into parameter interactions. Sci. Rep. 7:14721. doi: 10.1038/s41598-017-14187-1

Li, T., Chang, H., and Wu, J. (2013). Nonnegative signal decomposition with supervision. Math Proble Eng. 2013, 1-8. doi: 10.1155/2013/620537

McEniry, J., Forristal, P. D., and O'Kiely, P. (2011). Gas composition of baled grass silage as influenced by the amount, stretch, colour and type of plastic stretchfilm used to wrap the bales, and by the frequency of bale handling. Grass Forage Sci. 66, 277-289. doi: 10.1111/j.1365-2494.2011.00788.x

Muck, R. E. (2004). Effects of corn silage inoculants on aerobic stability. Trans. ASAE 47, 1011-1016. doi: 10.13031/2013.16571

Muck, R. E., Nadeau, E. M. G., McAllister, T. A., Contreras-Govea, F. E., Santos, M. C., and Kung, L. (2018). Silage review: recent advances and future uses of silage additives. J. Dairy Sci. 101, 3980-4000. doi: 10. 3168/jds.2017-13839

Muck, R. E., and Pitt, R. E. (1994). Aerobic deterioration in corn silage relative to the silo face. Trans. ASAE 37, 735-743. doi: 10.13031/2013.28134

Oliveira, A. S., Weinberg, Z. G., Ogunade, I. M., Cervantes, A. A. P., Arriola, K. G., Jiang, Y., et al. (2017). Meta-analysis of effects of inoculation with homofermentative and facultative heterofermentative lactic acid bacteria on silage fermentation, aerobic stability, and the performance of dairy cows. J. Dairy Sci. 100, 4587-4603. doi: 10.3168/jds.2016-11815

Oude Elferink, S. J. W. H., Krooneman, J., Gottschal, J. C., Spoelstra, S. F., Faber, F., and Driehuis, F. (2001). Anaerobic conversion of lactic acid to acetic acid and 1,2-propanediol by Lactobacillusbuchneri. Appl. Environ. Microbiol. 67, 125-132. doi: 10.1128/AEM.67.1.125-132.2001

Pahlow, G., Muck, R. E., Driehuis, F., Elferink, S. J. O., and Spoelstra, S. F. (2003). "Microbiology of ensiling," in Silage Science and Technology, eds D. R. Buxton, R. E. Muck, and J. H. Harrison (Madison, WI: American Society of Agronomy Inc), 31-93. doi: 10.2134/agronmonogr42.c2

Queiroz, O. C. M., Arriola, K. G., Daniel, J. L. P., and Adesogan, A. T. (2013). Effects of 8 chemical and bacterial additives on the quality of corn silage. J. Dairy Sci. 96, 5836-5843. doi: 10.3168/jds.2013-6691

Ranjit, N. K., and Kung, L. (2000). The effect of Lactobacillus buchneri, Lactobacillus plantarum, or a chemical preservative on the fermentation and aerobic stability of corn silage. J. Dairy Sci. 83, 526-535. doi: 10.3168/jds.S00220302(00)74912-5

Robinson, P. H., and Swanepoel, N. (2016). Impacts of a polyethylene silage pile underlay plastic with or without enhanced oxygen barrier (EOB) characteristics on preservation of whole crop maize silage, as well as a short investigation of peripheral deterioration on exposed silage faces. Anim. Feed Sci. Technol. 215, 13-24. doi: 10.1016/j.anifeedsci.2016.02.001
Sargent, R. W. H. (2000). Optimal control. J. Comput. Appl. Math. 124, 361-371. doi: 10.1016/S0377-0427(00)00418-0

Shan, G., Buescher, W., Maack, C., Lipski, A., Acir, I., Trimborn, M., et al. (2021). Dual sensor measurement shows that temperature outperforms $\mathrm{pH}$ as an early sign of aerobic deterioration in maize silage. Sci. Rep. 11:8686. doi: 10.1038/ s41598-021-88082-1

Shan, G., Buescher, W., Maack, C., Zhou, H., and Sun, Y. (2019). An automatic smart measurement system with signal decomposition to partition dual-source $\mathrm{CO}_{2}$ flux from maize silage. Sens. Actuators B 300:127053. doi: 10.1016/j.snb. 2019.127053

Sun, Y., Li, M., Cheng, Q., Jungbluth, K. H., Maack, C., Buescher, W., et al. (2015). Tracking oxygen and temperature dynamics in maize silage-novel application of a Clark oxygen electrode. Biosyst. Eng. 139, 60-65. doi: 10.1016/j. biosystemseng.2015.08.004

Tabacco, E., Piano, S., Revello-Chion, A., and Borreani, G. (2011). Effect of Lactobacillus buchneri LN4637 and Lactobacillus buchneri LN40177 on the aerobic stability, fermentation products, and microbial populations of corn silage under farm conditions. J. Dairy Sci. 94, 5589-5598. doi: 10.3168/jds.20114286

Weinberg, Z. G., and Ashbell, G. (2003). Engineering aspects of ensiling. Biochem. Eng. J. 13, 181-188. doi: 10.1016/S1369-703X(02)00130-4

Wilkinson, J. M., and Davies, D. R. (2012). The aerobic stability of silage: key findings and recent developments. Grass Forage Sci. 68, 1-19. doi: 10.1111/j. 1365-2494.2012.00891.x

Wilkinson, J. M., and Muck, R. E. (2019). Ensiling in 2050: some challenges and opportunities. Grass Forage Sci. 74, 178-187. doi: 10.1111/gfs. 12418

Conflict of Interest: VR and AM were employed by company ADDCON GmbH.

The remaining authors declare that the research was conducted in the absence of any commercial or financial relationships that could be construed as a potential conflict of interest.

Publisher's Note: All claims expressed in this article are solely those of the authors and do not necessarily represent those of their affiliated organizations, or those of the publisher, the editors and the reviewers. Any product that may be evaluated in this article, or claim that may be made by its manufacturer, is not guaranteed or endorsed by the publisher.

Copyright (C) 2021 Shan, Rosner, Milimonka, Buescher, Lipski, Maack, Berchtold, Wang, Grantz and Sun. This is an open-access article distributed under the terms of the Creative Commons Attribution License (CC BY). The use, distribution or reproduction in other forums is permitted, provided the original author(s) and the copyright owner(s) are credited and that the original publication in this journal is cited, in accordance with accepted academic practice. No use, distribution or reproduction is permitted which does not comply with these terms. 